\title{
ATTACHING FEELINGS AND EMOTIONS TO PROPOSITIONS. SOME INSIGHTS ON IRONY AND INTERNET COMMUNICATION
}

\author{
Francisco Yus \\ University of Alicante \\ Carretera San Vicente del Raspeig, s/n, 03690 San Vicente del Raspeig, \\ Alicante, Spain
}

\begin{abstract}
Feelings and emotions, typically non-propositional, play an important part in the eventual quality of the interpretations to which they are attached. However, relevance theory has preferred to focus on how hearers build up propositions that fill the gap between what is meant and what is eventually interpreted (Carston 2002). These are easier to handle, possess a mental representation and are a genuine object of analysis for linguistics (Chapman 2001, García-Carpintero 2010, Moeschler 2009). In this paper, a review is provided of several ways in which feelings and emotions play an important part in the eventual quality of interpretations, specifically focusing on irony (Yus 2016a, 2016b) and Internet-mediated communication (Yus 2016c, forthcoming).
\end{abstract}

Keywords: feelings, emotions, non-propositional effects, irony comprehension, Internet-mediated communication, cyberpragmatics, online identity

\section{INTRODUCTION}

Pragmatics deals with intentionally conveyed information; relevance theory (henceforth RT) further specifies its scope by claiming that it deals with ostensive-inferential communication, the one in which the communicator produces a stimulus which makes it mutually manifest to communicator and audience that the communicator intends, by means of this stimulus, to convey to the audience some information (Sperber and Wilson 1995: 63). As such, it mainly focuses on propositional information. Cases of non-verbal ostension are also treated as producing propositional implications, even if somewhat vague. This paper underlines the importance of feelings and emotions for communication and eventual relevance, both when intended in parallel to propositionally conveyed information (affective attitude) and when these leak, as it were, from the act of communication beyond the speaker's awareness and overt intentionality. The paper is organised as follows. Firstly, a brief introduction is provided of what may be communicated according to RT. Secondly, some comments on non-propositional feelings and emotions and their importance in communication are provided. Finally, two exemplifying cases are briefly commented upon: irony comprehension and online identity.

\section{RELEVANCE THEORY AND PROPOSITIONAL COMMUNICATION}

The prototypical form of communication according to RT is the propositional one, and what is inferred is either an explicit proposition (explicature) or an implicated one (implicature) or both. As Sperber and Wilson (1995: 57) explain, there is a very good 
reason to assume that what is communicated is propositional: it is relatively easy to say what propositions are, and how inference might operate over propositions. No one has any clear idea how inference might operate over non-propositional objects: say, emotions. "Propositional contents and attitudes thus seem to provide the only relatively solid ground on which to base a partly or wholly inferential approach to communication". However, these authors do acknowledge that some effects of communication do not fall neatly into the propositional mould and, in fact, they claim that it is a mistake to focus only on propositional communication, since there is a continuum of cases, from utterly intended explicatures and implicatures to implicatures which are merely made manifest, and to further modification of the mutual cognitive environment of speaker and hearer in which what is conveyed is, rather, rich, and not entirely foreseeable cognitive effects (p. 201; see also Sperber and Wilson 2015: 121).

Explicatures differ from the information coded, and interpretations may be more or less explicit. This departure from coded meaning is even more evident in the case of implicatures, which may also be arranged on a continuum between strong and weak. Consider this example (adapted from Carston 2009):

(1) Tom: How was the party? Did it go well?

Ann: There wasn't enough drink and everyone left early.

(2) a. There wasn't enough alcoholic drink to satisfy the people at the party and so everyone who came to the party left it early, roughly before 2 o'clock.

b. The party did not go well at all.

c. Parties in which alcohol is scarce and people leave early are not good.

d. Ann thinks alcohol is essential in parties.

e. Ann only enjoys herself at parties when she is surrounded by many people.

When Tom interprets Ann's utterance, he decodes her words and enriches them at the explicit level: the concept drink is adjusted into alcoholic drink; the scope of everyone is narrowed to "everyone at the party", and early has to be interpreted as the time in Tom and Ann's culture in which leaving a party at a certain time is considered early. The resulting proposition could roughly be the explicature in (2a). Of course, as an answer, she also strongly implicates (2b) (an implicated conclusion), in the sense that it is clear that she backs up this implicature. This is obtained by pairing the explicature in (2a) with encyclopaedic information about what it takes for parties to be successful (the implicated premise in (2c)). However, Tom may also derive further implicatures, this time weaker (Ann probably did not intend to communicate them, but these are anyhow triggered by her utterance), such as $(2 \mathrm{~d})$ or even weaker ones such as $(2 \mathrm{e})$, this time derived by Tom's sole responsibility.

\section{AFFECTIVE ATTITUDE: FEELINGS AND EMOTIONS}

What about the communication of feelings and emotions or the speaker's overall affective attitude? These are utterly important and may alter radically the eventual interpretation obtained and the relevance yielded by the act of communication. Feelings and emotions are treated here as roughly similar, although there is no agreement on the scope or overlapping between them (Caffi and Janney 1994: 327). The latter are typically as- 
sociated with acute and intense reactions to one's environment, often accompanied by physiological changes (Kidron and Kuzar 2002: 130), whereas the former seem to exhibit more stability. Affect seems to be an umbrella term for a whole range of feelings, moods and emotions (van Kleef 2016: 4). Similarly, Schwarz (2015: 161) differentiates between emotions and feelings, claiming that it is important to draw a distinction between them. Emotions would be defined as "a complex, internally represented knowledge system having a primarily evaluative function within the human organism." On the other hand, feelings would belong to the dimension of emotion that is experienced consciously. These are, therefore, mental representations.

\section{PRAGMATICS AND NON-PROPOSITIONAL INFORMATION}

As it has been argued in this paper, although pragmatics typically addresses intentionally conveyed propositional communication, non-propositional information (both intentionally and unintendedly transmitted) is also essential to determine the full extent of the addresser's intended interpretation and the quality of the addressee's eventual interpretation. Gibbs et al. (2002: 128) also comment that, in many cases of interpersonal communication, what is important is not the explicit propositions stated, but the more indeterminate non-propositional meaning and affect that is expressed and understood in the act of communication. In this way, propositional and non-propositional effects are intertwined. For instance, non-propositional effects may trigger or block propositional interpretations, and the latter can have an effect on the inference of non-propositional effects (Moeschler 2009: 460).

The range of communicative possibilities involving feelings and emotions, which can be grouped under the umbrella terms affective attitude (when intentional) and affective effect (when "exuded" unintentionally), are varied if we take into account axes such as propositional/non-propositional quality or acted upon/non-acted upon, together with the initial distinction between intentional and unintentional transfer of affective information. The term "acted upon" refers to the fact that feelings and emotions may be produced without the individual intervening in its extent and intensity, whereas on other occasions he/she does exert a control on their production. As Langlotz and Locher (2013: 91) summarize, while some cues may result from spontaneous expressions of genuine emotional states, other cues may be used strategically to emotionalize a given message in the absence of actual arousal. This entails degrees of control on this continuum from spontaneous to strategic emotional display. Van Kleef (2016: 57) adds that people express emotions to various degrees. At one end, experienced emotions which are expressed in an uncensored way, so that the interlocutor gets full insight into the individual's feelings. At the other end, suppressed expression of any experienced emotion, to the extent that their nonverbal or verbal expressions provide no clues as to their internal feeling states. And Wilson and Wharton (2006) illustrate this continuum of cases as follows: "A speaker's tiredness, boredom, frustration or anger may be revealed by her tone of voice or facial expression, even though she is trying to conceal them and even though it is clear to the audience that they are being accidentally revealed rather than intentionally conveyed. In more sophisticated cases, a speaker may covertly 
manipulate her tone of voice to suggest to an audience that she is accidentally betraying her feelings rather than wanting them to be recognised as part of her meaning".

Initially, if we take into account these axes, several possibilities may be listed:

1. Intentional/propositional. The addresser intentionally produces a propositional message whose content conveys his/her affective attitude.

2. Intentional/non-propositional/acted upon. The addresser intentionally conveys affective information non-propositionally, either nonverbally (gestures, vocal expressions) or attached to a verbal proposition (via intonation, gestures in parallel to verbal communication, etc.). Being aware of the affective information that should be conveyed, he/she acts upon this non-propositional act by enhancing it, reducing it, masking it, etc.

3. Intentional/non-propositional/not acted upon. The addresser intentionally conveys affective information non-propositionally, either nonverbally or attached to a verbal proposition. However, he/she does not feel the need to act upon this non-propositional act by enhancing it, masking it, etc.

4. Unintentional/non-propositional/acted upon. Beyond the addresser's intentions, some information exudes or leaks from him/her conveying his/her feelings or emotions. The addresser becomes aware of this leakage and acts upon its production by minimising it, masking it, etc.

5. Unintentional/non-propositional/not acted upon. Beyond the addresser's intentions, some information exudes or leaks conveying his/her feelings or emotions. The addresser does not feel the need to act upon its production, by minimising it, masking it, etc.

Among the aforementioned possibilities, one deserves further attention: the propositional vs. non-propositional information communicated by these feelings and emotions, either when attached to an utterance or when they are the only source of information (e.g. nonverbal behaviour). For RT, if these are intended, they typically entail a propositional quality, even if what is communicated is a range of impressions, rather than a fully-fledged proposition. An often cited example is the following (Sperber and Wilson 1995: 55):

(3) Mary and Peter arrive at the seaside. She opens the window overlooking the sea and sniffs appreciatively and ostensively. When Peter follows suit, there is no one particular good thing that comes to his attention: the air smells fresh, (...) it reminds him of their previous holidays, he can smell the sea (...); all sorts of pleasant things come to mind, and while, because her sniff was appreciative, he is reasonably safe in assuming that she must have intended him to notice at least some of them, he is unlikely to be able to pin her intentions down any further.

In this case, Mary's informative intention when sniffing the seaside air might be a number of assumptions that suddenly come to her mind upon sniffing, without necessarily intending, in a conscious way, to communicate any particular one of these assumptions. Maybe all that she wants is to share an impression with Peter. As such, it is partly precise and partly vague, and may be communicated as a weak implicature. But perhaps all that takes place in (3) is a mutuality of sub-propositional feelings and emotions triggered by the seaside, Mary perhaps being unable to pin them down propositionally and Peter being unable to infer beyond a general "she feels good about being at the seaside". 
In short, there would be a continuum of cases in emotional communication ranging from cases in which it is propositionally conveyed (explicitly, strongly implicated, weakly implicated) to cases in which what is conveyed and inferred remains at a sub-propositional level.

Furthermore, there is no reason why some non-propositional affective information could not be communicated besides (or even instead of) impression-related propositional implications. Illustrative examples are found in Strey (2016: 80), adapted as (4) below, and (5) from Wharton (2016):

(4) a. Jack: Let's go to the mall. Mary: (angrily) I'm feeling tired.

b. Mary feels tired.

c. Mary will not go to the mall.

d. When Mary is tired she never wants to go to malls.

e. Mary thinks that malls are crowded this time of year.

f. Mary feels angry at the prospect of having to go the mall.

(5) a. A: How's work going?

$\mathrm{B}$ : The boss is a bastard!

b. A: How's work going?

B: (Sighs wearily).

In the conversation (4a), Mary communicates (4b) explicitly (explicature). She also strongly implicates (4c), whereas other weaker implicatures such as (4d-e) are also triggered by Mary's utterance but may not be intended but extracted by Jack's sole responsibility. Crucially, Mary also communicates how she feels about Jack's question (the affective attitude in $4 \mathrm{f}$ ) by using a marked intonation and one of Jack's relevance-oriented inferential strategies will focus on working out the extent and intensity of these negative feelings, which will influence the inference of the propositional content to which Mary's intonation is attached (see also Moeschler 2009: 456 457).

Similarly, Wharton (2016) is right in pointing out that the difference between (5a) and (5b) is covered within RT by distinguishing strong from weak communication, and in parallel between strong and weak implicatures. Needless to say, a conclusion is strongly implicated to the extent that it must be derived in the course of constructing a satisfactory interpretation (and its derivation is clearly intended and backed up by the speaker). In this case, there is mainly a single, strongly manifest (i.e. implicated), assumption. In the case of weakly implicated assumptions, these help with the construction of a satisfactory interpretation, but are not essential or are even derived beyond the speaker's intentions. For Wharton, (5a) quite strongly implicates that all is not well at work, whereas the sigh in (5b) makes weakly manifest a wide array of weak implicatures, that is, it creates an impression rather than conveying a definite message. Again, in my opinion it is reductive to base all interpretations, including impressions, on a propositional mould, even if a whole range of possibilities are covered between strongly and weakly implicated assumptions. Although B may well have a propositional implication in mind, he/she may also hold a rather general feeling located on the negative side (being upset, fed up, angry...) and may only be capable of communicating these broad non-propositional feel- 
ings, and not a mentally represented implicated propositional assumption, even if it is an impression-based weak implicature. And the same applies to the addressee, who may be able to stand on B's shoes, as it were, to feel roughly the same broad negative feeling held by B, but without consciously reaching a propositional (even if weak) implicature.

\section{TWO CASE STUDIES}

Communication is partly propositional and partly non-propositional. Some information is propositional and intended, of an explicit (explicature) and/or implicit (implicature) quality. Some propositional information may also be derived beyond the speaker's intentions, but it is nevertheless triggered by his/her act of communication. Similarly, non-propositional information may be intended (e.g. to make sure that the interlocutor grasps how happy, angry etc. the addresser is), and some non-propositional information may also leak from the addresser's act of communication beyond his/her intentions, with some interesting communicative outcomes.

To account for this variability, in latest research (Yus 2015a, 2015b, 2015c, 2016b, 2017), an extension of the RT model has been proposed by including the analysis of contextual constraints and non-intended non-propositional effects. The former were initially intended to account for the fact that Internet communication is affected by a number of interface-related and user-related qualities that may also alter the eventual relevance of the act of communication. These are mainly related to the users' management of the interface, the kind of relationship existing between interlocutors, the user's personality, etc. The term contextual constraint is restricted to aspects that underlie the acts of communication and the users' interactions (i.e. they exist prior to the interpretive activity) and constrain their eventual (un)successful outcome. They frame, as it were, communication and have an impact not only on the quality of interpretation, but also on the willingness to engage in sustained virtual interactions. Constraints have an impact on (a) how much discourse is produced; (b) what kind of discourse is produced; (c) what kind of discourse is expected (audience validation); (d) what kind of discourse is possible (interface affordances); and (e) what kind of site is preferred (to channel communicative needs).

Secondly, the term non-intended non-propositional effect refers to feelings, emotions, impressions, etc. which are not overtly intended by the "sender user", but are nevertheless generated from the act of communication, and add (positively or negatively) to the cognitive effects derived from the interpretation of propositional content. These effects are important for eventual relevance, since they have an impact (a) on the positive/negative outcome of Internet acts of communication; (b) on the preference for a specific site, medium or channel; (c) on why certain interactions are (un)profitable despite the lack of/existence of interesting information; and (d) on how Internet interactions make users feel.

In short, the extended RT model would cover a broad range of communicated and/or inferred information: speaker-supported propositional content (explicatures, strong implicatures, propositional attitudes, some weak implicatures), hearer-supported weak implicatures (often beyond speaker's overt intentions), speaker-supported non-propositional feelings and emotions (affective attitude), and hearer-supported feelings and emotions 
beyond the speaker's intentions (affective effects), that is, non-intended non-propositional effects generated beyond the act of communication but which affect eventual relevance.

Among other research areas focusing on the importance of non-propositional information (e.g. feelings and emotions), either intended or unintendedly leaked, two examples are briefly commented upon below: irony comprehension and online identity. In the former, the addresser's affective attitude (feelings, emotions...) is important because it is intended and has to be recovered by the addressee as part of the relevant interpretive outcome. In the case of online identity, feelings and emotions are also important, but often because they are generated beyond the addresser's communicative intentions.

\subsection{Irony comprehension}

Beyond the traditional (and often inaccurate) approach to irony as communicating the opposite of what is literally stated, RT focuses on the fact that irony necessarily needs an opinion, norm, thought or utterance (called echo) to which a dissociative attitude is held. The recovery of an ironic interpretation depends, apart from a recognition of the utterance as echoic, on an identification of the source of the opinion echoed and on a recognition that the speaker's attitude to the opinion echoed is one of rejection or disapproval (dissociative attitude). In Yus (2016a) an example is cited: someone is inviting a friend to go to the beach and insisting that the weather is going to be fine, and upon arriving at the beach it stars pouring down. By saying "Nice weather we're having!" the speaker does not want to assert that it is inappropriate to say that the weather is fine when it is actually pouring down, but to dissociate himself/herself from his/her friend's opinion (and previous utterance) that the weather would be fine and that there was no reason not to go to the beach. Indeed, ironies make little sense if this attitude is not spotted, the interest lying, rather, in the speaker's attitude to an echoed thought or opinion.

Besides the speaker's dissociative attitude, a necessary element of irony is the need of a source for the echo. In short, the thought involved in ironic communication must be attributed to some actual person, or the speaker in a different context or humans in general, so that the underlying attitude is clearly ascribable as dissociative and not as that of endorsement or support. The notion of echo is intentionally broad, since it covers direct echoes of previous utterances, and also echoes of attributed thoughts (real or imaginary), social norms and expectations.

Sperber and Wilson (1995: 239-240) exemplify this need of an echo with Mary's comment in (6), which obviously aims to communicate (7), but whose main point is rather to communicate irony-related implicatures such as the ones listed in (8) (adapted and extended in Yus 2016a), all of which demand from Peter the identification of the utterance as echoic (and Mary's attitude involved as dissociative):

(6) Peter: It's a lovely day for a picnic.

[They go for a picnic and it rains].

Mary [sarcastically]: It's a lovely day for a picnic, indeed.

(7) Mary manifestly believes that it is not a lovely day for a picnic.

(8) It was wrong of Peter to say that it was a lovely day for a picnic.

Peter's judgement has been unsound.

It was Peter's fault that their day has been ruined.

Mary should never have trusted Peter in his weather prediction. 
However, an appropriate account of irony entails not only the identification of echo and attitude, but also the identification of the speaker's feelings and emotions (under the broad label of affective attitude) toward the source of the echo. Ironical interpretations differ radically depending on what affective attitude is held by the speaker when uttering the irony, which may not only influence the eventual choice of an interpretation, but also the ascription of irony as utterly offensive, mildly offensive, praising or humorous.

In a nutshell, being aware of the speaker's feelings and emotions can make interpretations differ radically. This view is more realistic in pairing propositional content (explicit, implicated, propositional attitude) with feeling- and emotion-related non-propositional effects (affective attitude) whose relevance lies in a certain mutuality, rather than a specific interpretation and which are also relevant even if not propositional. An example of how affective attitudes impact the propositional ironical interpretation is proposed in Yus (2016a). With the same initial part of a phone conversation in (9), the identification of the speaker's affective attitude (feelings, emotions) yields the different dialogue continuations and differing interpretive outcomes listed in (10), (11) and (12). The exchange in $(9-10)$ is a real phone conversation, while $(11-12)$ are my proposal of alternative continuations:

(9) [John calls Mary on the phone].

Mary: Hi John! How're things?

John: I am fine! I've just thought... Since Mary is always calling me, today for a change I'll make the call.

(10) Mary: Hahaha. Poor thing... You are right, I should call you more often, but you seem soooo happy to call your friend, don't you? hahaha.

John: Hehehe... Of course, Mary... A pleasure.

(11) Mary: I am sorry... I do call you every now and then... Don't be so angry.

John: Yeah, once a year more or less. I just think I deserve better.

(12) Mary: Hahaha. Poor thing... You are right, I should call you more often, but you seem soooo happy to call your friend, don't you? hahaha.

John: Actually, I am pissed off with having to call you all the time. You could make the effort to call me, couldn't you?

Mary: Oh... I am sorry... Don't be so angry. I never thought you'd be so upset.

In these examples, John has a dissociative attitude towards an opinion echoed of a commonsense quality: that nobody should always be the one calling. However, although the dissociative attitude is the same in (9-12), the final interpretation of this echoed opinion varies in each case because of the feelings associated with this opinion. In (10), John does think that it would be nice that Mary called him more often, but the feelings that he holds towards the echoed opinion are on the positive side, and Mary infers it correctly. By contrast, in (11) the feelings that he holds towards that opinion are on the negative side. Mary, again, correctly infers that the feelings associated with John's affective attitude are on the negative side. Finally, in (12) the dissociative attitude is correctly inferred but the feelings or emotions associated with the opinion echoed (the affective attitude) are misinterpreted, resulting in an erroneous interactional outcome.

Furthermore, it should be noted that what influences the eventual interpretation of an utterance is not only the identification of the speaker's affective attitude, but also the current feelings and emotions held by the hearer upon inferring the propositional 
content of the utterance. Very often, the same irony yields different interpretive outcomes because the hearer's feelings and emotions frame this interpretation and may lead it to different inferential outcomes.

Sperber and Wilson (1995: 240) do acknowledge the role of emotions in irony comprehension, stating that speakers use an echoic utterance to convey different attitudes and emotions "ranging from outright acceptance and endorsement to outright rejection and dissociation, and that the recognition of these attitudes and emotions may be crucial to the interpretation process". These authors opt for a picture of continuum, with different blends of attitude and emotion giving rise to a whole range of borderline cases which do not fit neatly into any existing scheme. In my opinion, affective attitude ascription should be incorporated into the RT model of irony comprehension, together with dissociative attitude and source of the echo, and the goal of a cognitive pragmatics should be to provide an account of how this affective attitude is spotted and how it influences the comprehension of the propositional content. And this is particularly noticeable in the case of ironical communication. Akimoto et al. (2014: 1168) are right in remarking that "verbal irony implies an underlying emotional attitude that differs from the meaning of what is actually said. Comprehension of irony is a representative example of the highorder sociolinguistic abilities of humans. It goes beyond literal understanding, integrating various types of information from the social context, including events, the speaker's beliefs and emotional attitudes, and paralinguistic cues such as facial expression. (...) Affective aspects are also important because they are not only involved in the processing of emotional interpretive cues, but are also closely related to the social function of irony, which is the reason why irony is used".

\subsection{Online identity}

Relevance is a comparative notion. Human cognition is capable, on every occasion, of assessing the cognitive effects and mental effort of competing propositional interpretations and automatically opt for the most relevant one in a specific context. However, relevance is also variable and subject to contextual features. As has been argued above, the eventual relevance may be affected by a number of factors that alter the intended relevance of an input even before it is produced (contextual constraints). Besides, addressees may find relevance in some inferred information that "leaks" beyond the propositional interpretation intended by the speaker (non-intended non-propositional effects). Needless to say, both non-propositional effects and contextual constraints exist in every act of communication, not only in Internet-mediated ones, but their influence is much more noticeable on the Internet, where interactions are often devoid of physical co-presence and typed utterances often exhibit a cues-filtered quality (Yus 2011, 2014, 2015a, 2015b, 2015c, 2015d, 2016d, 2016e, 2017).

Concerning online identity, by means of different types of uploaded (verbal-visual-multimodal) discourse, users position themselves as unique individuals and upload content on their profiles with expected audiences and interpretations, a kind of identity performance; and thanks to the affordances of new media, "addressee users" also coconstruct, co-produce text in a joint generation of content. This is particularly useful for identity-shaping strategies, since users manage and shape their personal identities with the aid of uploaded content and the impact that this content has on friends and acquaint- 
ances in terms of verbal replies, non-verbal reactions, etc., constituting a very relevant source of information for users beyond the objective information communicated by this self-related content. These constitute the main focus of analysis of a cyberpragmatics of online identity, since these are intentional acts of communication with intended (and expected) interpretations.

However, as has been argued in Yus (forthcoming), if we base the eventual relevance of Internet-mediated acts of communication only on the objective interest and value aroused by the intentional propositional content uploaded and transferred to other users, we will be unable to explain much of the appeal and the specificity of the Net in terms of user satisfaction and engagement (and eventual impact on the user's selfimage). The aforementioned additional terminology aims to complement propositional relevance so that a valid explanation of user (dis)satisfaction with online interactions may be provided. Certainly, users often do not only obtain relevance from the information provided by the content itself, but also (and nowadays especially) from the feelings and emotions that this content produces in addressee users, often beyond the interlocutors' awareness. The kind of effect that is important in this case is the one which exhibits a non-intentional and non-propositional quality, sometimes adding to the relevance of the propositional information and, crucially, often making up for the objective irrelevance of the information contained in the discourse communicated.

The eventual relevance of Internet-mediated acts of communication may be affected by the user's attributes and motivations, especially the user's personality and its management in the online/offline interface. Users frequently present an enhanced version of their selves and the act of presentation, even if faithful to the user's offline identity, is always constrained (qualitatively and quantitatively) by the user's personality, selfesteem, strength of ties, feelings and emotions. Besides, the user's content uploaded is also constrained by general expectations of conformity to norms and group-related expectations. This is especially the case of young users, always eager to find ways to leave a positive impression on their audiences and in the process they are constantly monitoring what their peers expect from them.

In the context of the topic of this paper, namely the role that feelings and emotions play in communication, non-intended non-propositional effects are important in the way they frequently hold the key to why Internet-mediated interactions turn out (ir)relevant regardless of the objective value of the content transferred to other users. Several of these effects have an impact of the user's self-concept or overall sense of identity. Among others, in Yus (forthcoming) the following are listed:

1. Feeling of connectedness, social awareness, feeling of being part of the interactions and friendships. Many users engage in "chained" acts of communication (typically trivial ones) because they eventually obtain an awareness of friends and peers and a feeling of connectedness. The notion of ambient awareness (Thompson 2008) points in this direction, since it refers to mutual awareness of one another arising from nonstop dialogues and uploaded content, often fragmentary, which nevertheless gives users a more or less thorough picture of their friends.

2. Feeling of being noticed by the network of friends, by the user's community, of feedback, of social support. Sustained interactions not only generate connectedness, but also feelings of in-group membership and communal support, of being "attached" to the other members of the group (Yus 2007). 
3. Generation of social capital. The term refers broadly to the benefits we receive from our social relationships, the resources linked to membership in a group or network of relationships, facilitating actions among these members. In this sense, virtual interactions aid in producing social capital that would otherwise be impossible if people only relied on physical co-presence for its generation.

4. Feeling of increased mutuality of information among friends and acquaintances. According to RT, the goal of human communication is not so much the mere transfer of information to others, but to generate a mutuality of this information (a mutual manifestness, in its terminology). The mutual satisfaction at sharing may be itself a source of satisfaction beyond the objective quality of the information exchanged.

5. Feeling of enhanced/decreased self-esteem and generation of positive/negative emotions. Finally, another positive/negative non-propositional effect has to do with selfesteem as managed and shaped through virtual interactions. On the positive side, virtual interactions may increase self-esteem. On the negative side, the user may end up with an offset of negative effects that have an impact on the user's self-esteem.

\section{CONCLUDING REMARKS}

Non-propositional feelings and emotions are important in human communication, both when intended as part of the eventual interpretation (the addresser's affective attitude) and when leaked unintentionally from the act of communication (affective effects). In this paper two examples have been provided illustrating this importance, one regarding intentional communication (feelings and emotions conveyed in ironical communication) and one related to these unintended feeling- and emotion-related effects (affective effects impacting the user's online identity).

(C) Francisco Yus, 2018

\section{REFERENCES}

Akimoto, Y., Sugiura, M., Yomogida, Y., Miyauchi, C.M., Miyazawa, S. \& Kawashima, R. (2014). Irony comprehension: Social conceptual knowledge and emotional response. Human Brain Mapping, 35, 1167-1178. doi: 10.1002/hbm.22242.

Caffi, C. \& Janney, R.W. (1994). Toward a pragmatics of emotive communication. Journal of Pragmatics 22, 325-373. doi: 10.1016/0378-2166(94)90115-5.

Carston, R. (2002). Thoughts and Utterances. Oxford: Blackwell.

Carston, R. (2009). Explicit/implicit distinction. In Cummings, L. (ed.), The Pragmatics Encyclopedia. London: Routledge, 154-162.

Chapman, S. (2001). In defence of a code: Linguistic meaning and propositionality in verbal communication. Journal of Pragmatics 33, 1553 - 1570. doi: 10.1016/S0378-2166(01)00009-1.

García-Carpintero, M. (2010). Linguistic meaning and propositional content. In Romero, E. \& B. Soria (eds.), Explicit Communication: Robyn Carston's Pragmatics. Basingstoke: Palgrave Macmillan, 75-91.

Gibbs, R.W., Leggitt, J.S. \& Turner, E.A. (2002). What's special about figurative language in emotional communication? In Fussell, S.R. (ed.), The Verbal Communication of Emotions. Interdisciplinary Perspectives. Mahwah: L.E.A., 125-149.

Kidron, Y. \& Kuzar, R. (2002). My face is paling against my will. Emotion and control in English and Hebrew. Pragmatics \& Cognition, 10 (1/2), 129-157. doi: 10.1075/pc.10.12.07kid. 
Langlotz, A. \& Locher, M.A. (2013). The role of emotions in relational work. Journal of Pragmatics, 58: 87-107. doi: 10.1016/j.pragma.2013.05.014.

Moeschler, J. (2009). Pragmatics, propositional and non-propositional effects: Can a theory of utterance interpretation account for emotions in verbal communication? Social Science Information, 48 (3), 447-464. doi: 10.1177/0539018409106200.

Sperber, D. \& Wilson, D. (1995). Relevance. Communication and Cognition (2nd ed.). Oxford: Blackwell.

Sperber, D. \& Wilson, D. (2015). Beyond speaker's meaning. Croatian Journal of Philosophy, XV (44), 117-149.

Schwarz-Friesel, M. (2015). Language and emotion. The cognitive linguistic perspective. In Lüdtke, U.M. (ed.), Emotion in Language. Theory - Research - Application. Amsterdam: John Benjamins, 157-173.

Strey, C. (2016). The Language of Emotions: An Ostensive-Inferential Study. Ph.D Thesis. Porto Alegre: Pontifical Catholic University of Rio Grande do Sul.

Thompson, C. (2008). Brave new world of digital intimacy. The New York Times, September 5th, Magazine.

van Kleef, G.A. (2016). The Interpersonal Dynamics of Emotion. Toward an Integrative Theory of Emotions as Social Information. Cambridge: Cambridge University Press.

Wharton, T. (2016). That bloody so-and-so has retired: Expressives revisited. Lingua, 175-176, 20-35. doi: 10.1016/j.lingua.2015.08.004.

Wilson, D. \& Wharton, T. (2006). Relevance and prosody. Journal of Pragmatics, 38(10), 15591579. doi: 10.1016/j.pragma.2005.04.012.

Yus, F. (2007). Virtualidades Reales. Nuevas Formas de Comunidad en la Era de Internet. Alicante: University of Alicante, Servicio de Publicaciones.

Yus, F. (2011). Relevance equations of effective Internet communication. In Pennock, B. \& Suau, F. (eds), Interdisciplinarity and languages. Current issues in Research, Teaching, Professional Applications and ICT. Frankfurt: Peter Lang, 65-86.

Yus, F. (2014). Turismo móvil: Discurso, interactividad y usabilidad en las 'apps' de turismo". Paper delivered at Discurso y Géneros del Turismo 2.0. University of Valencia and IULMA, Valencia, April.

Yus, F. (2015a). Should relevance theory analyse what is non-propositional, non-intentional but yet affects the eventual relevance? Paper delivered at Relevance Round Table Meeting 4. Kraków: Institute of English Studies, Jagiellonian University of Kraków, September.

Yus, F. (2015b). The discursive management of the phatic Internet (and how to explain it pragmatically). Paper delivered at Approaches to Digital Discourse Analysis (ADDA). Valencia (Spain), November.

Yus, F. (2015c). Broadening the (propositional) scope of pragmatics in order to address the (nonpropositional) quality of humorous effects. Paper delivered at I Workshop on Advanced Studies of Humor and Gender (WASHUM). Alicante (Spain): University of Alicante, November.

Yus, F. (2015d). The role of cognition and relevance in new digital narratives. In: Carpi, E. (ed.), Prospettive Multilingue e Interdisciplinari nel Discorso Specialistico. Pisa: Pisa University Press, $81-107$.

Yus, F. (2016a). Propositional attitude, affective attitude and irony comprehension. Pragmatics \& Cognition, 23(1), 92-116. doi: 10.1075/pc.23.1.05yus.

Yus, F. (2016b). Humour and Relevance. Amsterdam/Philadelphia: John Benjamins. 
Yus, F. (2016c). The phatic Internet. Networked feelings and emotions across the propositional-nonpropositional and the intentional-unintentional board. Paper delivered at the International Conference on Language and Emotion. Madrid, November.

Yus, F, (2016d). Towards a cyberpragmatics of mobile instant messaging. In: Romero-Trillo, J. (ed.), Yearbook of Corpus Linguistics and Pragmatics 2016: Global Implications for Culture and Society in the Networked Age. Berlin: Springer, 7-26.

Yus, F. (2016e). La seducción de lo no codificado. In Beguelin, V. \& Cordone, G. (eds.), Manifestaciones intermediales de la literatura hispánica del siglo XXI. Madrid: Visor, 33-53.

Yus, F. (2017). Contextual constraints and non-propositional effects in WhatsApp communication. Journal of Pragmatics, 114, 66 - 86. doi: 10.1016/j.pragma.2017.04.003.

Yus, F. (forthcoming) Relevance from and beyond propositions. The case of online identity. In Nasu, H. \& Strassheim, J. (eds.), Relevance and Irrelevance: Theories, Fa.

\title{
Article history:
}

Received: 03 July 2017

Revised: 20 July 2017

Accepted: 25 July 2017

\section{For citation:}

Yus, Francisco (2018). Attaching Feelings and Emotions to Propositions. Some Insights on Irony and Internet Communication. Russian Journal of Linguistics, 22 (1), 94-107. doi 10.22363/23129182-2018-22-1-94-107.

\section{Bionote:}

FRANCISCO YUS teaches pragmatics at the University of Alicante. He has a $\mathrm{PhD}$ in linguistics and he is full professor at the University of Alicante, Department of English Studies. Research interests: Pragmatics, Discourse Analysis, Media Discourse, Applied Linguistics, Sociolinguistics, Internet communication, Linguistic Politeness, Humor, Irony, Misunderstandings. Contact information: francisco.yus@ua.es

\section{FINANCE AND ACKNOWLEDGEMENTS:}

This research was supported by the EMO-FUNDETT research project, a coordinate project awarded by the Spanish Ministerio de Economía y Competitividad (FFI2013-47792-C2-1-P).

DOI: 10.22363/2312-9182-2018-22-1-94-107

\section{ВЫРАЖЕНИЕ ЧУВСТВ И ЭМОЦИЙ В ПРОПОЗИЦИИ: ВЗГЛЯД НА ИРОНИЮ И ИНТЕРНЕТ-КОММУНИКАЦИЮ}

\author{
Франсиско Юс \\ Университет Аликанте \\ Carretera San Vicente del Raspeig, s/n, 03690 San Vicente del Raspeig, \\ Alicante, Испания
}

Чувства и эмоции, обычно не связанные с пропозицией, играют большую роль в процессе интерпретации того, к чему они относятся. Тем не менее, теория релевантности предпочтительно акцентирует внимание на том, как слушающие строят предположения, заполняющие разрыв между 
тем, что имелось в виду, и что было понято (Carston 2002). Эти предположения обладают ментальной репрезентацией и являются объектом изучения лингвистов (Chapman 2001, García-Carpintero 2010, Moeschler 2009). Статья представляет собой обзор некоторых способов выражения чувств и эмоций, которые играют важную роль в интерпретации сказанного. Автор уделяет особенное внимание иронии (Yus 2016a, 2016b) и интернет-коммуникации (Yus 2016c, в печати).

Ключевые слова: чувства, эмоџии, понимание иронии, интернет-коммуникация, киберпрагматика, он-лайн идентичность

\section{История статьи:}

Дата поступления в редакцию: 03 июля 2017

Дата принятия к печати: 25 июля 2017

\section{Для цитирования:}

Yus, Francisco (2018). Attaching Feelings and Emotions to Propositions. Some Insights on Irony and Internet Communication. Russian Journal of Linguistics, 22 (1), 94-107. doi 10.22363/23129182-2018-22-1-94-107.

\section{Сведения об авторе:}

ФРАНСИСКО ЮС преподает прагматику в университете Аликанте на кафедре английского языка. Защитил диссертацию по лингвистке. Сфера научных интересов: прагматика, дискурсанализ, медиа-дискурс, прикладная лингвистика, социолингвистика, интернет-коммуникация, вежливость, ирония и юмор. Контактная информация: e-mail: francisco.yus@ua.es

\section{ФИНАНСИРОВАНИЕ И БЛАГОДАРНОСТИ:}

Статья является частью исследовательского проекта EMO-FUNDETT (Эмоции и язык в действии: эмотивная оценка функций разных текстов и рабочих контекстов) за номером FFI201347792-С2-1-Р. Этот проект финансируется Министерством экономики и конкуренции Испании. 